\title{
Potential of Urban Kampong Area as a Tourism Destination (Case Study: Kampong Jayengan Surakarta)
}

\author{
Rina Kurniati*, Parfi Khadiyatna, and Josephin Fenatama Angel \\ Program Study of Urban and Regional Planning, Departement Urban and Regional Planning, 50275 \\ Semarang City, Indonesia
}

\begin{abstract}
Kampong Jayengan was formed in the early 19th century, when the royal family asked the jewelers from Martapura to come to Surakarta. Craftsmen work with ethnic Chinese gold entrepreneurs in making jewelry for the royal family. They settled and married with local residents, so that cultural events took place such as the distribution of 'Samin' porridge and the "Jarwana" cultural parade. The Surakarta government established Jayengan as a creative economy industrial area. Constraints that occur: lack of tourism promotion, cultural events only once a year, lack of availability of raw materials, lack of internal support, competition with other industries. The purpose of the research is to make the strategy of tourism development. The study was conducted questionnaires to identify activities, authentic values and tourist infrastructure. The identification results are made into a questionnaire variable and then processed into an External Internal Matrix (IE). IE Matrix Jayengan readiness in cell I. It can be concluded that the right strategy is Grow and Build with the development of tourist activities, authentic values and the construction of tourist infrastructure. Outcome of this study provide direction in developing strategies for urban villages as tourist destination.
\end{abstract}

Keyword: Creative industry ,Cultural acculturation, Kampong Jayengan

\section{Introduction}

The historical background of the urban village becomes an inherent identity. City identity is an image formed from a reflection of social, economic, and cultural activities. Kampong Jayengan is one of the historic urban villages in the city of Surakarta. Jayengan was originally formed as a residential area consisting of the Banjar Tribe since

1746 who worked as a jewel trader and craftsman [1]. The craftsmen settled and continued to trade in gem crafts until now. The characteristic of the Jayengan handicraft is jewelery

*Corresponding author: rina.kurniati@pwk.undip.ac.id 
with Javanese traditional touches. Cultural tourism needs to be modified to attract the attention of tourists but it must still present authentic value of the product. [2].

Jewelery handicraft production activities are the identity of Kampong Jayengan. The unique characteristics of location, locality, and authentic values are the main motivations for people visiting cultural tourism destinations [3]. Authentic value can be seen with the transfer and sustainability of culture that is maintained from generation to generation [4]. Kampong Jayengan has the appeal of handicraft jewelery products and culinary, the diversity of local culture, Forum Jayengan Kampung Permata organization, has amenities such as accommodation, transportation and accessibility, electricity, clean water, and telecommunications [5].

The development of the creative economy is expected to be a solution to economic problems such as low economic growth, unemployment, poverty, and lack of industrial competitiveness [6]. Socio-cultural activities are also routinely carried out once a year. The activity was manifested in the distribution of samin porridge and "Jarwana" cultural parade. Cultural acculturation occurs when there are two or more different cultures that combine to influence each other without eliminating the identity or equality of each culture [7].

\section{Research Method}

The method used in this research is quantitative. Data collection techniques used were observation and questionnaires. The questionnaire will be given to 30 entrepreneurs. The results of processing the questionnaire data will be processed into IE Matrix readiness Jayengan.

The results of observations are then analyzed as internal and external potential. Internal potential consists of strengths and weaknesses. External potential consist of opportunity and threat. The next step is to analyze internal and external potential in quantitative models. The results of these quantitative calculations will be illustrated in the IE Matrix.The IE matrix will be used to formulate alternative strategies.

\section{Kampong Jayengan as Tourist Destination}

The potential of the Kampong Jayengan is handicraft products, cultural activities and infrastructure. The economic activity of jewel crafts is the main attraction of Jayengan. Jewelery crafts have been the main activity of the Jayengan's society since the 19th century.

In addition to the economy, cultural activities are also a tourist attraction. Kampong Jayengan's cultural activity is distribution of "Samin" porridge and "Jarwana" cultural parade. Samin porridge is a typical food of the Banjar tribe. Samin porridge is believed to cure various diseases. Jarwana cultural parade also shows the identity of Kampong Jayengan. Jarwana cultural parade is a carnival of Javanese, Banjar and Chinese culture. The carnival shows the characteristics of cultural acculturation in Kampong Jayengan. Kampong Jayengan is also has tourism infrastructure. The infrastructure that is available is an information center, workshop, jewelry shop, traditional restaurant, gift shop, and hotel, and a showroom.

\section{Theories}

Human activity is the process of social life that is realized through the actions of individuals who participate in it [8]. Human activity consists of socio-cultural and economic activities. The form of a religious system (belief) the reality of society's life that can not be separated [9]. It is a form of social and cultural life of the community. Economics is also inseparable from human life. Economic activity consists of the processes of buying and selling, 
producing, trading, marketing goods, collaboration with various parties such as companies, investors, and the government [10].

Authentic value is an identity that must be maintained. Authentic values are original and real [11]. The authenticity of cultural tourism is a social concept developed by society activities [12]. The development of tourism based on local wisdom must pay attention to the characteristics of crafts, tourism promotion and information, and the provision of infrastructure [13].

Infrastructure is supporting tourism activities. Tourism infrastructure needed is lodging, restaurants, transportation, tourist attractions and showroom [14]. The infrastructure needed for craft-based tourism is information centers, retail shops, open plazas, exhibition halls, places for artists to discuss, educational facilities and workshops [15].

\section{Potentials Kampong Jayengan as a Tourist Destination}

\subsection{IE Matrix for Jayengan Readiness and Handicraft Product}

\subsubsection{IE Matrix Jayengan Readiness}

In making an IE matrix, the first thing to do is calculate the weight of internal and external factors. Factor weights were obtained from processing the results of the questionnaire. The next step is calculating the score. Score calculation is obtained by the formula:

$$
\text { score }=\text { weight } x \text { rating }
$$

After getting the total score per variable, the total score of total internal potential and external potential is added. The following are the results of calculating internal and external potential scores:

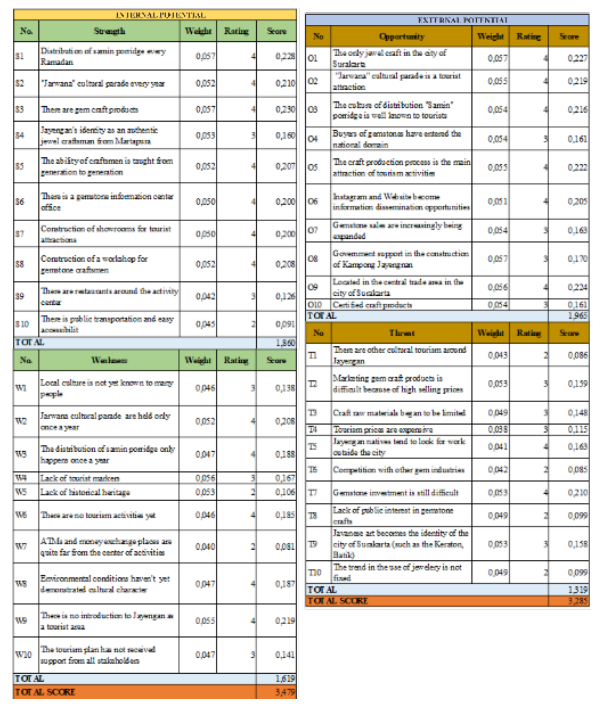

Fig. 1. Internal and External Factor Score Calculation

Internal and external score calculation results are then entered into the IE matrix. This is the result of processing the IE jayengan readiness matrix: 


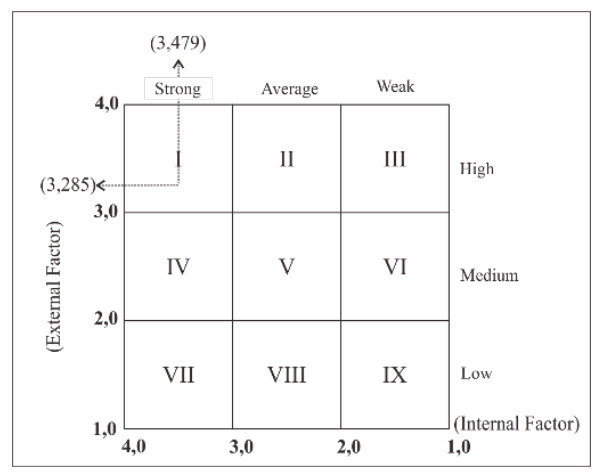

Fig. 2. IE Matrix Jayengan Readiness

The analysis shows that the Jayengan readiness matrix is in Cell I. Internal potential value $=3.479$ and external potential value $=3.249$. The right development strategy for this cell is Grow and build. Strategy for Grow and Build is Intensive (market penetration, market development, and product development) or integration (backward integration, forward integration, and horizontal integration). This study focused on intensive strategies. Strategy focuses on market development. The market in this research is the physical development of the area as a place for tourist attractions.

\subsection{IE Strategic for Development Jayengan Potential Cultural Tourism}

\subsubsection{Tourism Activities Zoning}

The zoning area of activity consists of the main and supporting activities. The main activities are information centers, jewelery shops and jewel workshops. Supporting activities include restaurants, hotels and gift shops.

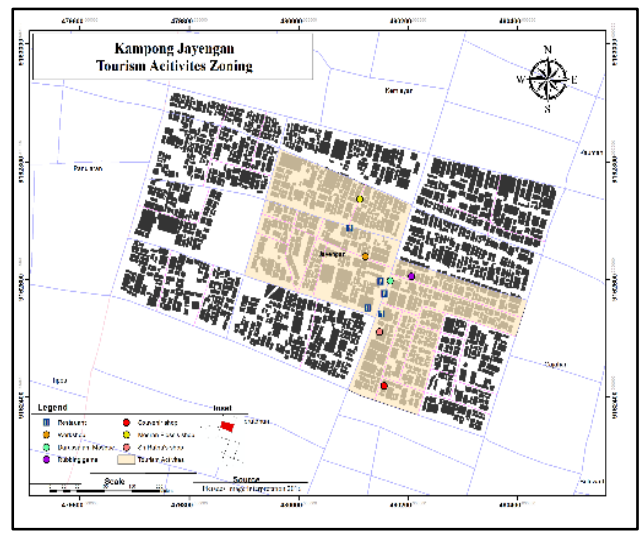

Fig. 3. Tourism Activities Zoning

\subsubsection{Tourism Infrastructure Development}

1. Construction of a 'Welcome' Pillar and Information Center 
Tourism information development is planned at the main activity center. The construction site is next to the information center building. The next development plan is the construction of a welcome pillar at the entrance and exit of the center for tourism activities.

\section{Showroom's Construction}

The construction of the showroom is planned to consist of two floors. The first floor contains exhibition space. Exhibition space can be a place for product marketing. The second floor is a workshop and education room. Visitors can see the production process in this space.

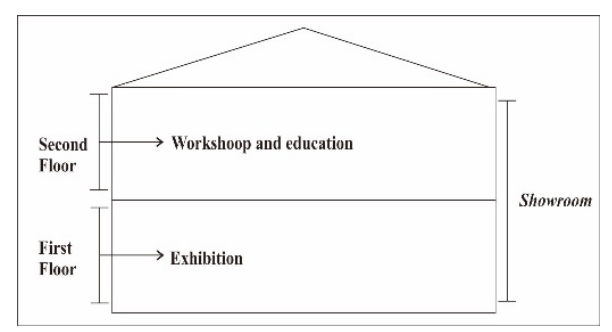

Fig. 4. Showroom's Plan Construction 


\section{Pedestrian and Parker's Improvement}

The planned pedestrian width is 2.5 meters. The pedestrian will contain lighting, seating, pedestrian paths, diafble paths, trash bins, shade trees and street lights. Another plan is parking improvement. Planned improvement are the addition of parking markers between vehicles.

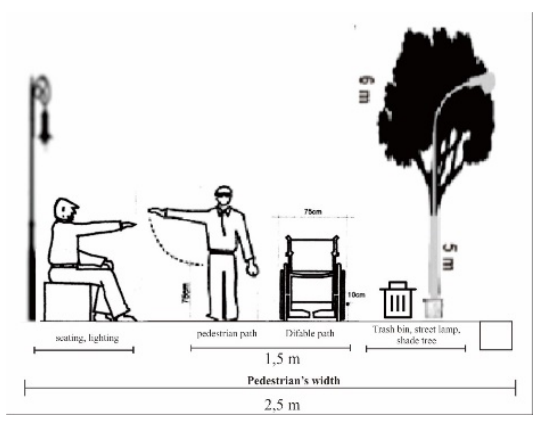

Fig. 5. Pedestrian's Improvement Plan

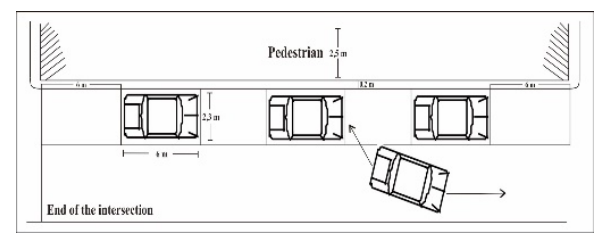

Fig. 6. Parker's Improvement Plan

\section{Conclusion}

Based on the results of the study it can be seen that Jayengan is suitable for cultural tourism. The potential are indicated by the character traits of tourism based on community activities and also maintains authentic value of Javanese handicraft products. This is consistent with the theory that cultural tourism is based on society activities and maintains the authentic value of the region. Based on the results of the IE Matrix analysis, it is known that the most appropriate strategy is grow and build. The planned strategy are to make zoning tourism activities and development of tourism infrastructure. The planned strategy is based on the theory that cultural tourism is based on society activities, authentic values and the availability of tourism infrastructure. This research can be utilized in the development of tourist activity centers. So the planned development of tourism areas can be focused on the most strategic areas. 


\section{References}

[1] W. Astuti, Qomarun, A. Fabela, R. A. Putri, dan D. W. Astuti, Challenging Potency of Jayengan : New Opportunity for Kampung-Based Tourism in Surakarta, 4, 245256 (2017)

[2] H. S. Cahyadi, Authenticity and Commodification of Culture at Puri Anyar Kerambitan as Royal Tourism Attraction in Tabanan Regency, Bali Province, Indonesia, 3, 1 (2015)

[3] W. Astuti, A. S. Permana, Qomarun, A. Febela, dan Rufia Andisetyana, Integrated Planing Model of Creative Industry Based Kampung Tourism in Jayengan

Surakarta, Indonesia, 15, 63-76 (2017)

[4] R. Kreuzbauer dan J. Keller, "The Authenticity of Cultural Products: A Psychological Perspective, 26, 417-421 (2017)

[5] L. P. Suryono, W. Astuti, dan M. J. Rahayu, Tingkat Kesiapan Komponen Wisata Kreatif Jayengan Kampoeng Permata Berdasarkan Stakeholder, 7, 43 (2017)

[6] N. J. Setiadi, Development of The Creative Economy In The City of Bandung: Measuring Creative Behavior among Indonesian Creative Workers, 453, 9 (2012)

[7] Kodiran, Akulturasi sebagai Mekanisme Perubahan Kebudayaan, 1, 87 (2013)

[8] B. Karpatschof, Human Acitivity. The Anthropology of Activity Theory, 12, 173232, (2007)

[9] C. B. Umanailo, Ilmu sosial budaya dasar Penulis, 2, 46-47 (2015)

[10] N. Klimova, Distribution Models Of Market Economy, 14, 48-69, (2016)

[11] S. Frisvoll, Conceptualising authentication of ruralness, 43, 272-296 (2013)

[12] P. F. Xie dan G. Wall, "Visitors' perceptions of authenticity at cultural attractions in Hainan, China, 4, 353-366 (2002)

[13] S. A. Rahmi, Pembangunan Pariwisata Dalam Perspektif Kearifan Lokal, 6, 76-84 (2016)

[14] I. B. D. Setiawan, Identifikasi Potensi Wisata Beserta 4A (Attraction, Amenity, Accessbility, Ancilliary) Di Dusun Sumber Wangi, Desa Pemuteran, Kecamatan Gerokgak, Kabupaten Buleleng, Bali, 6 (2015)

[15] M. W. Destiyanto, Wisata kerajinan logam bejijong, 5 (2014) 